\title{
Hevein: an antifungal protein from rubber-tree (Hevea brasiliensis) latex
}

\author{
Jan Van Parijs ${ }^{1}$, Willem F. Broekaert ${ }^{1}$, Irwin J. Goldstein ${ }^{2}$, and Willy J. Peumans ${ }^{1}$ \\ ${ }^{1}$ Laboratorium voor Plantenbiochemie, Willem De Croylaan 42, B-3000 Leuven, Belgium \\ ${ }^{2}$ Department of Biological Chemistry, University of Michigan, Ann Harbor, MI 84109-0606, USA
}

Received 12 February; accepted 25 Juli, 1990

\begin{abstract}
Several chitin-binding proteins were isolated from the "bottom fraction" of Hevea brasiliensis (Müll.) Arg. latex. One of these chitin-binding proteins is hevein, a small monomeric protein which strongly resembles the lectin from stinging nettle (Urtica dioica L.). Like the latter, hevein showed strong antifungal activity against several fungi in vitro. The possible involvement of this protein in the defense against invasion by potentially pathogenic fungi is discussed.
\end{abstract}

Key words: Chitin - Fungus - Hevea (antifungal protein) - Lectin - Plant-pathogen interaction - Resistance (to fungi)

\section{Introduction}

Hevein is a small $(4.7 \mathrm{kDa})$ cysteine-rich protein in the latex of the rubber tree (Hevea brasiliensis), and was originally described by Archer (1960). It is one of the major proteins in the lutoids, which are small vacuolederived organelles (Archer et al. 1969). Although nothing is known about the physiological function of this abundand latex protein, the striking homology between the amino-acid sequence of hevein (Walujono et al. 1975) and that of Urtica dioica agglutinin (UDA) (Chapot et al. 1986) may provide some clues.

This UDA is a non-catalytic carbohydrate-binding protein (lectin) with specificity towards substrates containing $\mathrm{N}$-acetyl-glucosamine such as chitin (Peumans et al. 1983). It occurs at relatively high concentrations in the underground organs (roots and rhizomes) of stinging nettle. We have recently demonstrated that UDA inhibits growth of many chitin-containing fungi in

Abbreviations: FPLC $=$ fast protein liquid chromatography; $\mathrm{M}_{\tau}=$ apparent molecular mass; SDS-PAGE = Sodium dodecyl sulphatepolyacrylamide gel electrophoresis; UDA $=$ Urtica dioica agglutinin; WGA = Wheat-germ agglutinin vitro (Broekaert et al. 1989), indicating that it may be an antifungal agent in vivo.

In this paper we describe the isolation of hevein by affinity chromatography on chitin and provide evidence for its antifungal activity in vitro.

\section{Material and methods}

Materials. Freeze-dried "bottom fraction" of the latex of Hevea brasiliensis was kindly provided by Dr. S. Soemitro from the Rubber Research Institute, Kuala Lumpur, Malaysia.

A pure samle of hevein was obtained from Dr. J.J. Beintema, Rijksuniversiteit Groningen, The Netherlands. Phycomyces blakesleeanus Burgeff, strain K1 (ATCC 5633) was a gift of Dr. A. Van Laere, Catholic University of Leuven, Belgium. Pyrenophora triticirepentis (Died.) Drechs. strain 45101 and Trichoderma hamatum (Bonard.) Bain. strain 10401 were provided by Dr. A. Vanachter, Catholic University of Leuven, Belgium. Other microorganisms used in this study were Septoria nodorum Berk. (MUCL 30111); Pyricularia oryzae Cav. (MUCL 30166); Botrytis cinerea (Pers.) Fr. (MUCL 30158); Fusarium culmorum (W.G. Smith) Sacc. (IMI 180420); and Fusarium oxysporium f. sp. pisi (van Hall) Snyd. \& Hans. (IMI 236441).

Crude crab-shell chitin and chitosan were obtained from Sigma St. Louis, MO., USA). Chitotriose was prepared from crude chitin by the method of Rupley (1964). Tritiated chitin was prepared as described by Broekaert et al. (1988).

Purification of chitin-binding proteins from latex. Six grams of lyophilyzed bottom fraction from latex of $H$. brasiliensis were extracted in $150 \mathrm{ml}$ of $50 \mathrm{mM}$ acetic acid containing $0.2 \mathrm{M} \mathrm{NaCl}$. Thiourea was added to a final concentration of $10 \mathrm{mM}$ in order to inhibit polyphenoloxidase activity. The extract was brought to $\mathrm{pH} 4.0$ with $1 \mathrm{~N} \mathrm{NaOH}$ and centrifuged for $10 \mathrm{~min}$ at $20000 \cdot \mathrm{g}$. The supernatant was loaded on a chitin column and the column washed with $0.2 \mathrm{M} \mathrm{NaCl}$ until the $\mathrm{A}_{280}$ fell below 0.01 . The bound proteins were eluted from the chitin column with $0.5 \mathrm{M}$ acetic acid. The peak fractions were diluted tenfold and brought to $\mathrm{pH} 3.8$ with $2 \mathrm{~N}$ $\mathrm{NaOH}$. In a final purification step we chromatographed the affinitypurified fraction on a Pharmacia (Uppsala, Sweden) Mono-S cation-exchange column using a Pharmacia fast protein liquid chromatography (FPLC) system. Washing was done with $50 \mathrm{mM}$ sodium-formate buffer ( $\mathrm{pH}$ 3.8) and the column eluted using a linear gradient of increasing $\mathrm{NaCl}$ concentration (from 0.0 to $0.4 \mathrm{M}$ ) at a flow rate of $2 \mathrm{ml} \cdot \mathrm{min}^{-1}$. Peak fractions were collected and used for further analysis. The yield was $56 \mathrm{mg}$ of pure hevein. 
Purification of chitinases. Triticum aestivum chitinase and Nicotiana tabacum chitinase were prepared as described by Broekaert et al. (1988).

Sodium dodecyl sulphate-polyacrylamine gel electrophoresis ( $S D S-P A G E$ ) was performed using a discontinuous system according to Laemmli (1970) on a $12-25 \%(\mathrm{w} / \mathrm{v})$ acrylamide gradient gel. Hevein samples were somewhat overloaded since the protein rapidly eluted from the gel upon destaining. However, quick observations were possible as the stained hevein band eluted slower than the dye (Walujono et al. 1975). Since both hevein and UDA yielded diffuse bands we improved the resolution of the gels by changing the acrylamide concentration and the shape of the gradient. The best resolution was obtained under the conditions described above. It is worth mentioning that the exact relative molecular masses $\left(M_{r}\right)$ of hevein and UDA cannot be determined using SDS-PAGE because of the anomalous behaviour of these proteins in this type of electrophoresis (Tata 1975).

Molecular-weight determination of hevein by gel filtration was estimated using an FPLC-system (Pharmacia) equipped with a Superose-12 column (HR 10/30) and an on-line ultraviolet monitor $(280 \mathrm{~nm})$. Flow rate was $20 \mathrm{ml} \cdot \mathrm{h}^{-1}$ in all experiments. Reduction and carboxyamidation of proteins was performed according to Ansari and Mage (1976).

Amino-acid analysis was performed by the University of Michigan Protein Sequencing Facility using phenyl thiocarbamyl amino acids (Koop et al. 1982).

Enzyme assays. The following enzyme assays were done according to previously described protocols: chitinase (Broekaert et al. 1988), chitosanase (Price and Storck 1975), $\beta-\mathrm{N}$-acetylglucosaminidase (Boller and Kende 1979), and lysozyme (Jollés 1962). Trypsininhibitor tests were done as described by Walsh (1970). Agglutination assays were done as in Peumans et al. (1982).

Growth inhibition assay. Fungal spores were suspended at a density of approx. $10^{5}$ spores $\cdot \mathrm{ml}^{-1}$ in potato dextrose broth (Difco Laboratories, Detroit, Mich. USA). The suspensions were sonicated with a needle probe (Labsonic 2000; Braun, Melsungen, FRG) at $50 \mathrm{~W}$ for $1 \mathrm{~min}$ in order to disrupt spore clumps. The constitutive dormant spores of Phycomyces blakesleeanus were activated by heating at $50^{\circ} \mathrm{C}$ for $5 \mathrm{~min}$. Aliquots of this spore suspension were incubated at $22^{\circ} \mathrm{C}$ in flat-bottom multiwell plates (NUNC, Linbro, Denmark) until the hyphae of the germlings reached an average length of about $40 \mu \mathrm{m}$ (stage 1). Then, test solutions were added to the stage- 1 germlings, and the flasks re-incubated at $22^{\circ} \mathrm{C}$ until the control germlings ( $50 \mu \mathrm{l}$ of sterile water added) reached an average length of approx. $500 \mu \mathrm{m}$ (stage 2). The average hyphal lenght of stage- 2 cultures was determined from photomicrographs made with an inverted microscope (M40; Wild, Heerbrugg, Switzerland). Growth was expressed as the increase in average hyphal length from stage 1 to stage 2 , relative to that of control cultures. Tests were performed in triplicates. Mean values were calculated and used in the figures.

\section{Results}

Purification and characterization of hevein. The sediment formed after low-speed centrifugation $(1000 \cdot g)$ of $H$. brasiliensis latex, the so-called bottom fraction, was used as a starting material for the isolation of hevein. Extraction at low $\mathrm{pH}$ and affinity chromatography on chitin resulted in a protein mixture that yielded six different peaks upon high-performance ion-exchange chromatography (Fig. 1). The protein from one of the major peaks (peak 1) was tentatively identified as hevein based on its amino-acid composition (Table 1).

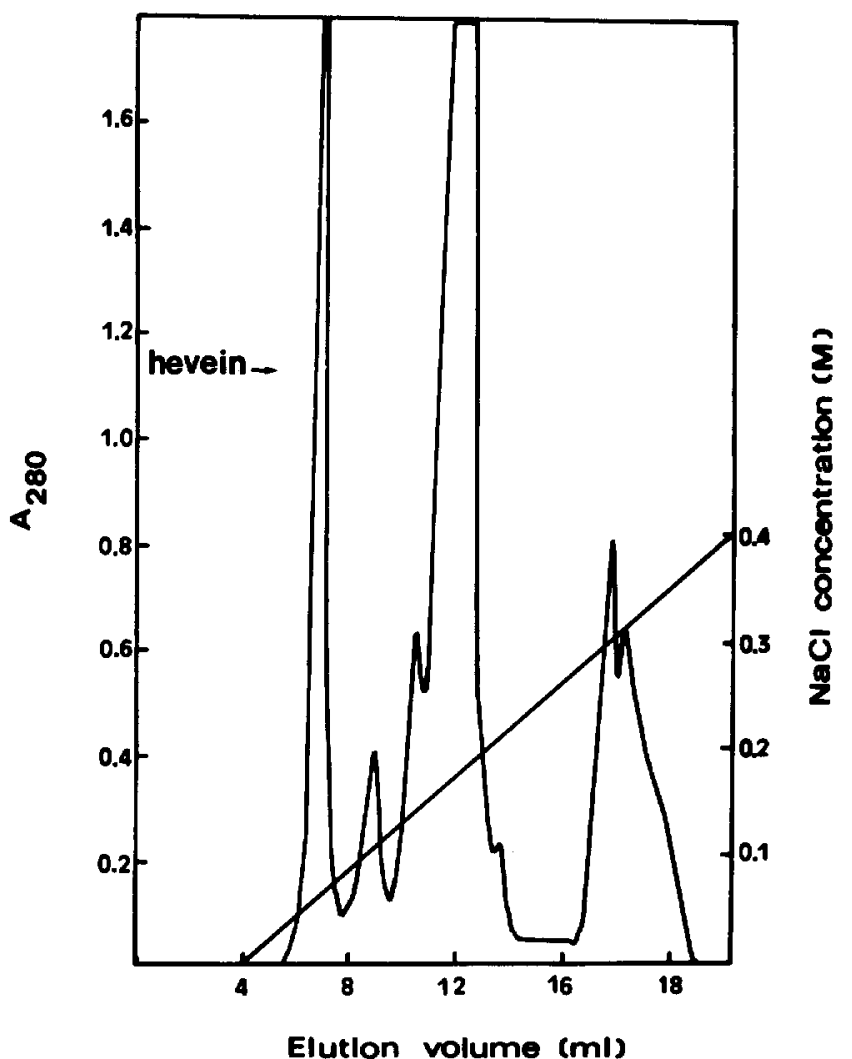

Fig. 1. Ion-exchange chromatography of chitin-binding proteins from the bottom fraction of Hevea brasiliensis latex. Latex proteins $(5 \mathrm{mg})$ isolated by affinity chromatography on chitin were loaded on a Mono-S column equilibrated with $50 \mathrm{mM}$ sodium-formate buffer $(\mathrm{pH} 3.8)$. After washing the column with $4 \mathrm{ml}$ of butter, proteins were eluted using a linear gradient of increasing $\mathrm{NaCl}$ concentration (from 0.0 to $0.4 \mathrm{M}$ ) at a flow rate of $2 \mathrm{ml} \cdot \mathrm{min}^{-1}$. The first major peak (peak 1) is hevein (arrow, left)

Table 1. Amino-acid composition of hevein. 1, Composition of hevein (peak I fraction) purified by affinity chromatography on chitin; 2, composition according to Archer (1960); 3, composition according to Walujono et al. (1975)

\begin{tabular}{llll}
\hline Amino acid & 1 & 2 & 3 \\
\hline Ala & 1.3 & 0.8 & 1.0 \\
Cya & 8.0 & 8.0 & 7.9 \\
Asp & 7.6 & 5.1 & 6.2 \\
Glu & 6.0 & 3.9 & 5.5 \\
Phe & 0.1 & 0.0 & 0.0 \\
Gly & 5.8 & 3.9 & 4.9 \\
His & 0.9 & 1.4 & 1.4 \\
Ile & 0.2 & 0.0 & 0.0 \\
Lys & 2.1 & 2.1 & 2.0 \\
Leu & 2.3 & 2.1 & 1.9 \\
Met & 0.0 & 0.0 & 0.0 \\
Pro & 2.5 & 2.1 & 1.9 \\
Arg & 1.2 & 1.9 & 1.0 \\
Ser & 3.5 & 5.0 & 3.7 \\
Thr & 1.1 & 0.9 & 0.9 \\
Val & 0.2 & 0.7 & 0.0 \\
Tyr & 1.1 & 1.9 & 1.0 \\
Total & 43.9 & 39.8 & 39.3 \\
\hline
\end{tabular}




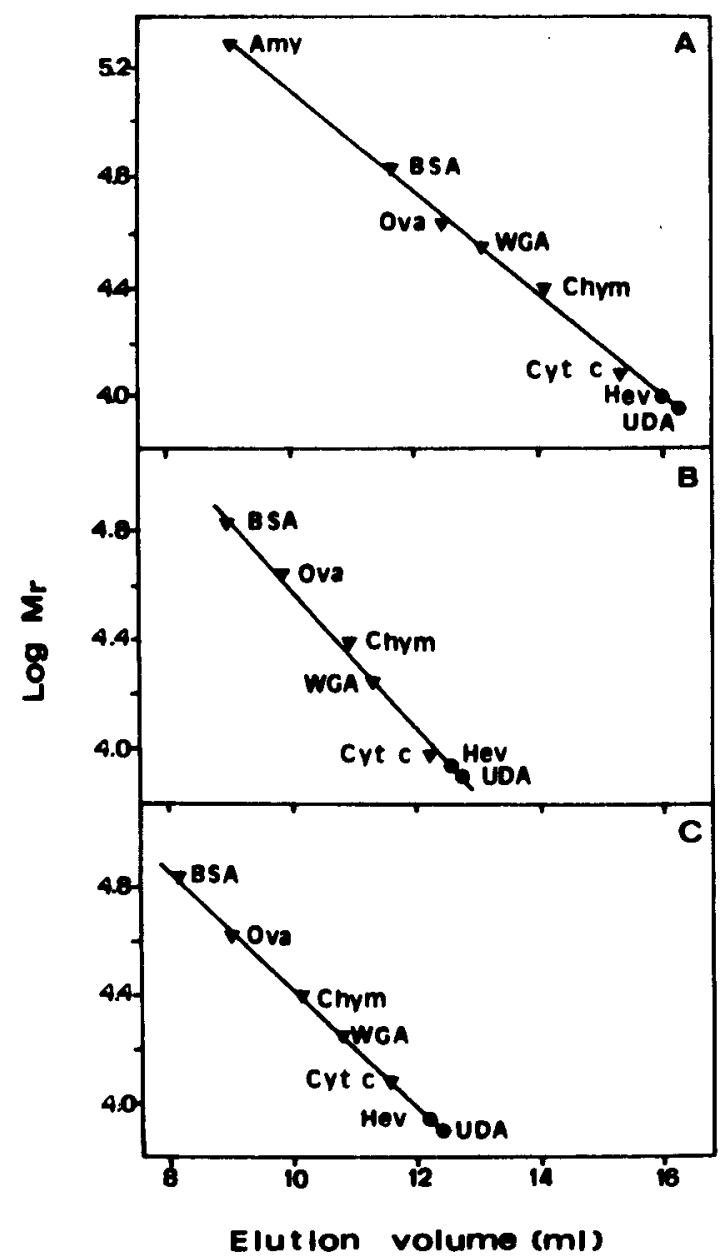

Fig. 2A-C. Molecular-weight determination of chitin-binding proteins by high-performance gel filtration. Analyses were done on an FPLC system (Pharmacia) and an in-line ultraviolet-monitor $(280 \mathrm{~nm})$. Elution rate was $20 \mathrm{ml} \cdot \mathrm{h}^{-1}$ in all experiments. A Running buffer was phosphate-buffered saline containing $10 \mathrm{mM}$ chitotriose. The column was calibrated with 20 - $\mu$ g amounts of $\beta$-amylase $(A m y, 200 \mathrm{kDa})$, bovine serum albumin $(B S A, 67 \mathrm{kDa})$, ovalbumin (Ova, $45 \mathrm{kDa})$, wheat-germ agglutinin ( $W G A, 36 \mathrm{kDa})$, chymotrypsinogen (Chym, $25 \mathrm{kDa}$ ) and cytochrome $c(C y t c, 12.4 \mathrm{kDa})$. Hevein and UDA were analysed on a parallel run. B Running buffer was $6 \mathrm{M}$ guanidinium-Cl' $100 \mathrm{mM}$ Tris- $\mathrm{HCl}(\mathrm{pH} 8.7)$. Calibration proteins were the same as in the legend of $\mathbf{A}$, except that $\beta$-amylase was omitted. $\mathbf{C}$ Hevein, UDA, and calibration proteins were reduced and carboxyamidated before analysis. Running buffer was $6 \mathrm{M}$ guanidinium- $\mathrm{Cl}$ ' $100 \mathrm{mM}$ Tris- $\mathrm{HCl}(\mathrm{pH} 8.7)^{\prime} 5 \mathrm{mM}$ dithiotreitol. In all three experiments, hevein purified by affinity chromatography on chitin migrated from the column in exactly the same position as a hevein sample purified by classical methods (Walujono et al. 1975)

Molecular-weight estimation of the material from peak 1 by gel filtration under native conditions yielded an $\mathrm{M}_{\mathrm{r}}$ value of $10 \mathrm{kDa}$ (Fig. 2A). Gel filtration under denaturing conditions $(6 \mathrm{M}$ guanidinium- $\mathrm{HCl})$ indicated an $\mathrm{M}_{\mathrm{r}}$ of $9 \mathrm{kDa}$ for both the unreduced protein (Fig. 2B) and the reduced and carboxyamidated protein (Fig. 2C). Upon SDS-PAGE, the protein migrated as a single band with an $M_{r}$ of about $14 \mathrm{kDa}$ (Fig. 3). By any of these methods the protein from peak 1 consistently comigrated with a pure hevein sample, isolated by conventional pur-

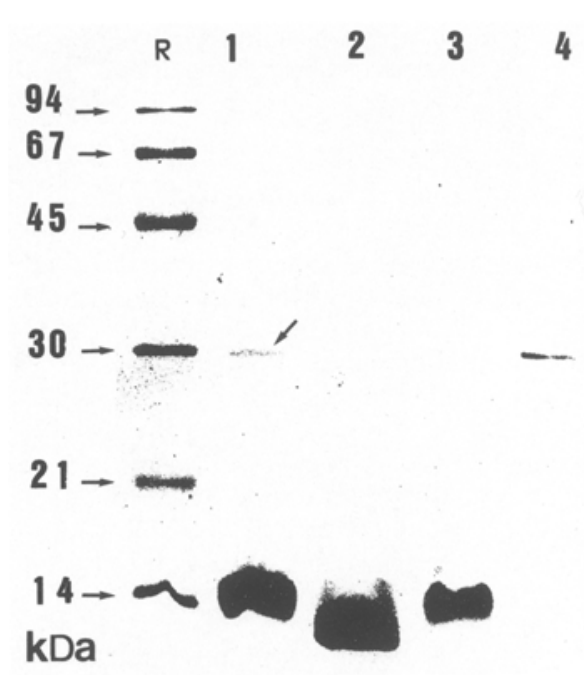

Fig. 3. Analysis of hevein, UDA and chitinase by SDS-PAGE. Hevein, purified as described by Walujono et al. (1975), UDA, peak-1 material (hevein purified by affinity chromatography on chitin), and tobacco chitinase were loaded, in the order given, on lanes 1,2, 3 and 4. Molecular-weight markers (lane $R$ ) were phosphorylase b $(94 \mathrm{kDa})$, bovine serum albumin $(67 \mathrm{kDa})$, ovalbumin $(45 \mathrm{kDa})$, carbonic anhydrase $(30 \mathrm{kDa})$, soybean trypsin inhibitor $(21 \mathrm{kDa})$ and lysozyme $(14 \mathrm{kDa})$. Samples were somewhat overloaded since hevein eluted rapidly from the gel upon destaining. Quick observations, however, were possible since the dye eluted more rapidly than the stained protein bands. Note the contamination by a $30-\mathrm{kDa}$ protein (probably a chitinase) in the so-called pure hevein sample isolated by the method of Walujono et al. (1975) (lane 1 , arrow)

ification methods (Walujono et al. 1975), thus confirming its identity as hevein (Figs. 2, 3). Moreover, as shown in Fig. 3, our hevein preparation was not visibly contaminated with chitinase.

The carbohydrate-binding properties of hevein were further evaluated by chromatographing it on different affinity matrices (Fig. 4). The binding of purified peak-1 material to chitin was almost quantitative, with recoveries of up to $80 \%$ upon desorption with $25 \mathrm{mM}$ chitotriose. Similar chromatographic patterns were obtained when conventionally purified hevein was used instead of peak-1 material. No binding affinity of hevein or peak-1 material could be observed on matrices consisting of immobilized $\mathrm{N}$-acetylglucosamine-containing glycoproteins, such as fetuin-agarose or ovomucoidagarose (Sigma). Besides the chitin-binding activity, hevein did not show any agglutination or enzymatic activity. It failed to agglutinate untreated or trypsintreated erythrocytes from rabbit, pigeon or human origin. Furthermore, tests for chitinase, chitosanase, $\beta$-N-acetylglucosaminidase, lysozyme or trypsin-inhibitor activity were negative even when hevein was included at up to $1 \mathrm{mg} \cdot \mathrm{ml}^{-1}$ in the appropriate assay mixtures.

Antifungal properties of hevein. The antifungal activity of chitinase-free hevein preparations was assessed by determining the effect of increasing concentrations on the extension of fungal hyphae. As shown in Fig. 5, hevein was inhibitory to all of the eight fungi tested (Botrytis 


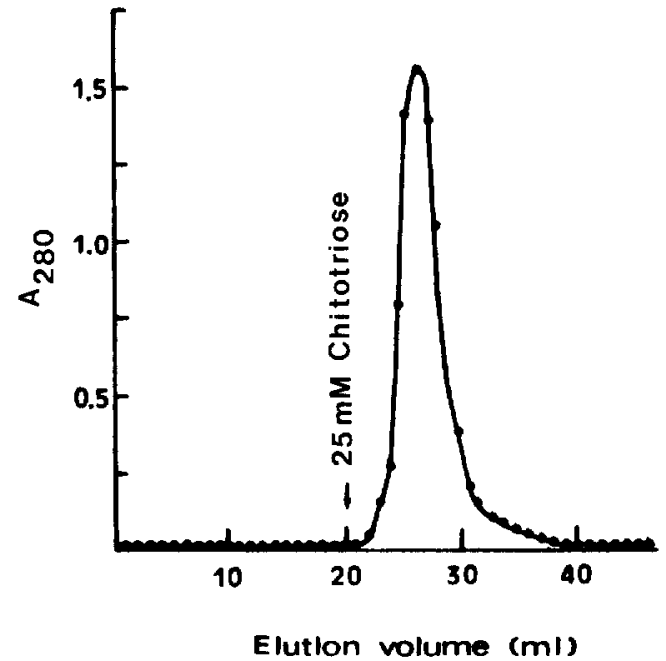

Fig. 4. Affinity chromatography of hevein on chitin. A hevein sample consisting of $2.6 \mathrm{mg}\left(6.5 \mathrm{~A}_{280}\right.$ units) of peak-1 material (see Fig. 1) in $1 \mathrm{ml} 50 \mathrm{mM}$ sodium-acetate buffer ( $\mathrm{pH} \mathrm{3.8)}$ was applied on a column ( $5 \mathrm{ml}$ bed volume) of chitin. The column was washed with $20 \mathrm{ml}$ sodium-acetate buffer and the hevein eluted with sodium-acetate buffer containing $25 \mathrm{mM}$ chitotriose

cinerea, Fusarium culmorum, Fusarium oxysporum f. sp. pisi, Phycomyces blakesleeanus, Pyrenophora triticirepentis, Pyricularia oryzae, Septoria nodorum, and Trichoderma hamatum).

The concentration required for $50 \%$ growth inhibition $\left(\mathrm{IC}_{50}\right)$ was taken as a measure of the inhibitory potency of hevein on a given fungus, thus allowing direct comparison with known antifungal proteins such as tobacco chitinase and UDA (Table 2). From this comparison it appears that tobacco chitinase is the most potent inhibitor of the saprophytic fungi $P$. blakesleeanus and T. hamatum. The plant pathogenic fungi included in our test were best inhibited by UDA, which was three to five times more potent than hevein. Tobacco chitinase did not cause growth inhibition of the pathogens, even when applied at $1.0 \mathrm{mg} \cdot \mathrm{ml}^{-1}$.

A morphological effect often associated with heveinmediated fungal growth inhibition is the formation of thick hyphae with buds (Fig. 6). Similar effects were observed with UDA, but not with tobacco chitinase. The latter more frequently caused lysis at the hyphal tips.

The antifungal activity of hevein appeared to be extremely heat-resistent, as it was not destroyed by a treatment at $90^{\circ} \mathrm{C}$ for $10 \mathrm{~min}$. Heat-inactivation of the antifungal activity of hevein ran parallel with its chitinbinding capacity, as indicated by the values of growth inhibition after addition of chitotriose (Table 3). Addition of anti-chitinase antiserum did not inhibit the antifungal activity of hevein, indicating that the antifungal activity did not result from contaminating chitinases.

\section{Discussion}

We have developed a simple method for the isolation of hevein based on its binding affinity for chitin. Our hevein

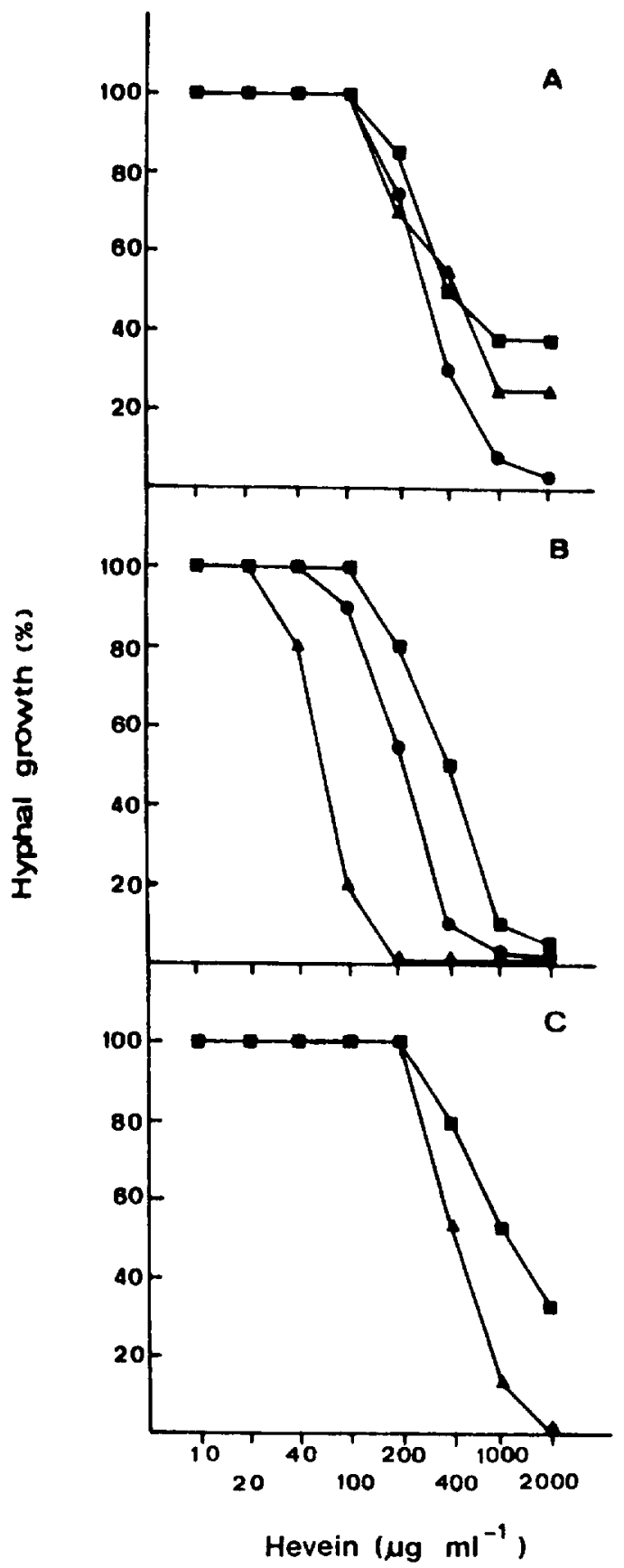

Fig. 5A-C. Antifungal activity of hevein. Hyphal growth of germlings was measured at varying concentrations of hevein using the following test organisms: A - - Pyricularia oryzae; $\mathbf{A}-\mathbf{\Lambda}$, Fusarium culmorum; $-\bullet$, Pyrenophora tritici-repentis. B $\mathbf{\square -}$, Botrytis cinera; $\bullet \bullet$, Phycomyces blakesleeanus; $\mathbf{\wedge}-\mathbf{\Lambda}$, Trichoderma hamatum. C --, Fusarium oxysporum f. sp. pisi; - - Septoria nodorum. Relative hyphal growth is expressed as percentage of the hyphal growth of control cultures, and data are means of three independent experiments. Ratios of SEs to means were less than $10 \%$

preparation was indistinguishable from a previously characterized hevein sample (Walujono et al. 1975) with respect to its amino-acid composition, elution behaviour upon gel filtration, affinity chromatography on chitin and ion-exchange chromatography on a Mono-S col- 

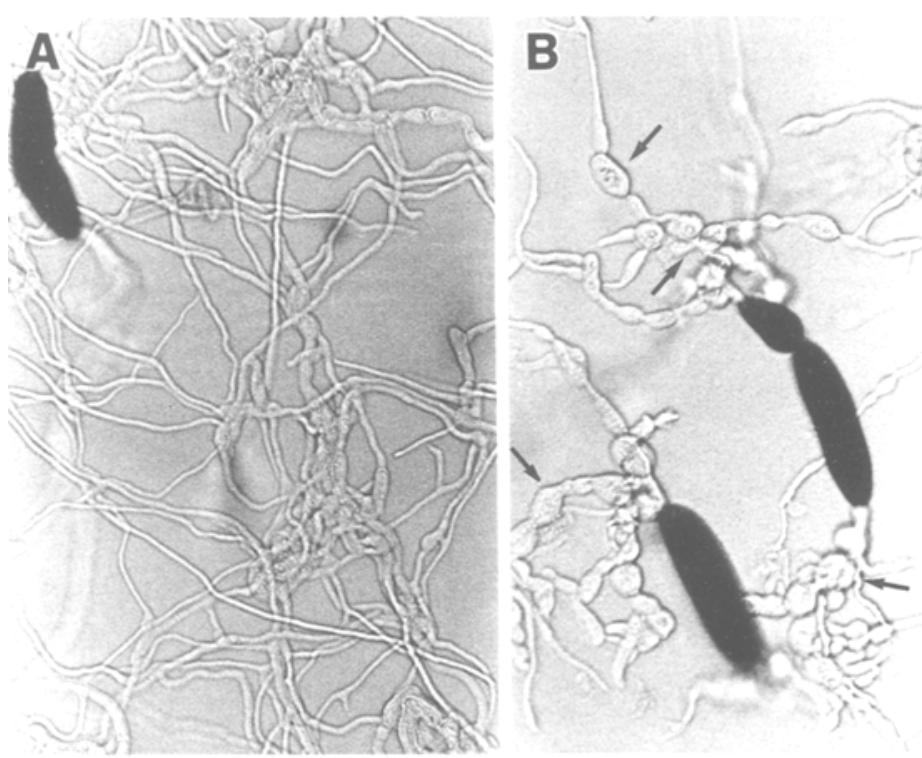

Fig. 6A-C. Morphological effect of hevein treatment on hyphae of the fungus Pyrenophora tritici-repentis. A Untreated germlings (control) at $8 \mathrm{~h}$ post germination. B Germlings treated with $500 \mu \mathrm{g} \cdot \mathrm{ml}^{-1}$ hevein. Note the decrease in length as compared to

Table 2. Antifungal potency of hevein in comparison with UDA and chitinase from Nicotiana tabacum (NTC). N.D. = Not determined

\begin{tabular}{lccr}
\hline & \multicolumn{2}{l}{$\begin{array}{l}\text { Concentration }\left(\mu \mathrm{g} \cdot \mathrm{ml}^{-1)}\right. \\
\text { required for } \\
50 \% \text { inhibition of } \\
\text { hyphal growth }\end{array}$} \\
\cline { 2 - 4 } & Hevein & UDA & NTC \\
\hline Botrytis cinerea & 500 & 40 & $>1000$ \\
Fusarium culmorum & 600 & N.D. & $>1000$ \\
Fusarium oxysporum & 1250 & N.D & $>1000$ \\
Phycomyces blakesleeanus & 300 & 100 & 20 \\
Pyrenophora tritici-repentis & 350 & N.D. & N.D. \\
Pyricularia oryzae & 500 & N.D. & N.D. \\
Septoria nodorum & 500 & 35 & N.D. \\
Trichoderma hamatum & 90 & 45 & 2 \\
\hline
\end{tabular}

umn, and relative electrophoretic mobility upon SDS-PAGE.

The chitin-binding properties of hevein are not surprising, taking into consideration its amino-acid sequence homology with other chitin-binding proteins such as the lectins WGA (Wright et al. 1985), UDA (Chapot et al. 1986) and many plant chitinases (Boller 1988). Moreover, when spotted onto nitrocellulose paper, hevein weakly cross-reacts with antibodies raised against WGA or UDA (Broekaert 1988), which also points to some structural homologies. Unlike the lectins (Kocourek and Horejsi 1981) UDA and WGA, however, hevein does not agglutinate red blood cells. It is not clear at present whether this is because there is only a single functional carbohydrate-binding site per molecule or to an inappropriate binding specificity of the carbohydratebinding site(s).

Molecular-weight estimation of hevein by gel filtra-

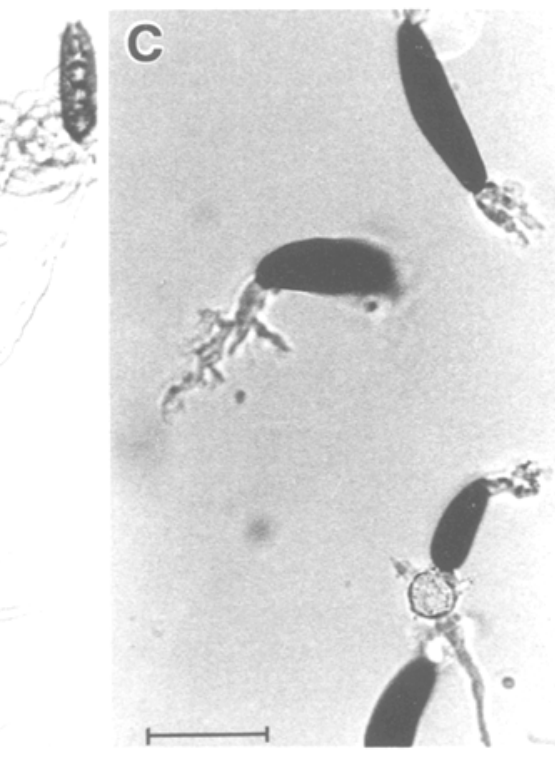

A. Germlings treated with hevein (or UDA, not shown) developed thick hyphae with buds (see arrows). C Germlings, totally inhibited by $2 \mathrm{mg} \cdot \mathrm{ml}^{-1}$ hevein. Bar $20 \mu \mathrm{m}$

Table 3. Reversibility of antifungal activity of hevein and tobacco chitinase $(N T C)$ by different treatments. Inhibition results are expressed as percentage of the activity of untreated samples and are mean values of three independent experiments. Ratios of SEs to mean values were $15 \%$ or less. Untreated samples $(50 \mu 1)$ contained $800 \mu \mathrm{g} \cdot \mathrm{ml}^{-1}$ hevein or $40 \mu \mathrm{g} \cdot \mathrm{ml}^{-1}$ chitinase in $100 \mathrm{mM}$ sodiumphosphate buffer ( $\mathrm{pH}$ 6). Chitotriose was added to the samples at a final concentration of $10 \mathrm{mM}$. Immunoprecipitation was done by adding $10 \mu \mathrm{l}$ of antiserum to $90-\mu \mathrm{l}$ samples containing $80 \mu \mathrm{g}$ of hevein (or $4 \mu \mathrm{g}$ chitinase) in sodium-phosphate buffer. After standing for $1 \mathrm{~h}$ at $37^{\circ} \mathrm{C}$ and $24 \mathrm{~h}$ at $4^{\circ} \mathrm{C}$, the precipitates were removed by centrifugation and the supernatants tested

\begin{tabular}{llc}
\hline Samples & \multicolumn{2}{l}{ Growth inhibition (\%) } \\
\cline { 2 - 3 } & Hevein & NTC \\
\hline Untreated & 100 & 100 \\
Chitotriose $(10 \mathrm{mM})$ addition & 25 & 20 \\
Immunoprecipitation with anti- & 87 & 0 \\
$\quad$ chitinase (supernatant) & & \\
Heating for $10 \mathrm{~min}$ at $90^{\circ} \mathrm{C}$ & 95 & 0 \\
Heating for $10 \mathrm{~min}$ at $100^{\circ} \mathrm{C}$ & 19 & 0
\end{tabular}

tion under both native and denaturing conditions indicated an $M_{\mathrm{r}}$ value between 9 and $10 \mathrm{kDa}$. It appears therefore that hevein behaves as a monomeric protein, as previously observed by Tata (1975). Analysis by SDS-PAGE yielded a somewhat higher value $(14 \mathrm{kDa})$, but overestimation is commonly observed by this method with proteins rich in cysteine and glycine. The obvious discrepancy between our results $(9 \mathrm{kDa})$ and the value calculated by Walujono et al. (1975) $(4.7 \mathrm{kDa})$ is difficult to explain. Although hevein behaves as a 9-kDa polypeptide in our experiments it cannot be excluded that this value is an overestimation resulting from the particular amino-acid composition and molecular structure of this small protein. 
The antifungal properties of chitin-binding lectins have been a matter of controversy ever since the report of Mirelman et al. (1975) on the inhibitory effect of WGA on fungal growth. Schlumbaum et al. (1986) have presented convincing evidence that chitinase-free preparations of WGA or potato lectin are devoid of any antifungal activity (Broekaert et al. 1989). However, we recently proved that another chitin-binding lectin, UDA, is a potent inhibitor of chitin-containing fungi, and that its antifungal effect is different from that of chitinases (Broekaert et al. 1989). We now demonstrate that hevein also inhibits several chitin-containing fungi, though to a somewhat lesser extent than UDA. For several fungi, however, hevein is a more potent inhibitor than chitinase, which excludes the possibility that the antifungal effects are merely caused by the presence of contaminating chitinase. Our observation that most fungi are not inhibited by the chitinase is consistent with that of Mauch et al. (1988) who showed that in most cases chitinase must act in coordination with $\beta-1,3$-glucanase in order to exert notable antifungal characteristics.

At present it is not known why some chitin-binding proteins like hevein and UDA exhibit antifungal properties while others, like WGA or potato lectin apparently do not. It is tempting to speculate that the antifungal properties of hevein and UDA are somehow related to their particularly small size $(4.7$ and $8.5 \mathrm{kDa}$, respectively), WGA and potato lectin being much larger proteins ( $36 \mathrm{kDa}$ and $100 \mathrm{kDa}$, respectively). Hevein and UDA may be small enough to penetrate through the fungal cell wall and reach the plasmamembrane, where they may have an effect on the active sites involved in cell-wall morphogenesis. Hevein might interfere with growth by binding or cross-linking newly synthesized chitin chains. In this way the "steady-state" model of hyphal growth proposed by Wessels (1988) is disturbed. Alternatively, the delicate balance between chitin synthesis and selective hydrolysis of preformed chitin chains might be interrupted (Cabib 1987).

The presence of high concentrations of hevein, a protein with antifungal properties, in the latex of the rubber tree, poses intriguing questions about its physiological function. It has previously been proposed that the presence of lysozyme in tissues making the first contact with possible pathogens at a site of wounding (as the latex does in this case) might be an effective system for the self-protection of the plant (Tata et al. 1983). Recent$\mathrm{ly}$, the localization and mechanism of action of chitinase was examined by Mauch and Staehelin (1989) who showed that chitinase is located in vacuolar particles in the cell. Only when the invading fungus breaks through the cell wall and plasmamembrane is there a cascade of lytic enzymes which attack the hyphae of the intruder. Since hevein is localized in the vacuole-derived lutoid bodies of Hevea brasiliensis, a similar mechanism of action may be involved.

This work is supported in part by NIH grant and grants of the National Fund for Scientific Research (Belgium): W.J.P. is senior research associate, and W.F.B. senior research assistant of this fund. J.V.P. receives a fellowship of the Belgian Instituut tot
Aanmoediging van het Wetenschappelijk Onderzoek in Nijverheid en Landbouw.

\section{References}

Ansari, A.A., Mage, R.G. (1976) An evaluation of effectiveness of bio glass in molecular sieving of polypeptides in guanidine hydrochloride. Anal. Biochem. 74, 118-125

Archer, B.L. (1960) The proteins of Hevea brasiliensis latex. 4. Isolation and characterization of crystalline hevein. Biochem. J. 75, 236-240

Archer, B.L., Audley, B.G., Sweeney, G.P., Tan, Chee Hong (1969) Studies on composition of latex serum and 'bottom fraction' particles. J. Rubber Res. Inst. Malays. 21, 560-569

Boller, T. (1988) Ethylene and the regulation of antifungal hydrolases in plants. In: Oxford surveys of plant molecular and cell biology, vol. 5, pp. 145-174, Miflin, B.J., ed. Oxford University Press, Oxford

Boller, T., Kende, H. (1979) Hydrolytic enzymes in the central vacuole of plant cells. Plant Physiol. 63, 1123-1132

Broekaert, W.F. (1988) Chitinases and chitin-binding lectins in plants: a biochemical and physiological study of their role in the natural protection of plants against fungi. Dissertationes de agricultura 165, Fakulteit Landbouw-wetenschappen, K.U. Leuven

Broekaert, W.F., Van Parijs, J., Allen, A.K., Peumans, W.J. (1988) Comparison of some molecular, enzymatic and antifungal properties of chitinases from thorn-apple, tobacco and wheat. Physiol. Mol. Plant Pathol. 33, 319-331

Broekaert, W.F., Van Parijs, J., Leyns, F., Joos, H., Peumans, W.J. (1989) A chitin-binding lectin from stinging nettle rhizomes with antifungal properties. Science $245,1100-1102$

Cabib, E. (1987) The synthesis and degradation of chitin. Adv. Enzymol. 59, 59-101

Chapot, M.P., Peumans, W.J., Strosberg, A.D. (1986) Extensive homologies between lectins from non-leguminous plants. FEBS Lett. 195, 231-234

Jollés, P. (1962) Lysosomes from rabbit spleen and dog spleen. In: Methods in enzymology, vol. V, pp. 137-140, Colowick, S.P., Kaplan, N.O., eds. Academic Press, New York London

Kocourek, J., Horejsi, V. (1981) Defining a lectin. Nature 290, 188

Koop, D.R., Morgan, E.T., Tarr, G.E., Coon, M.U. (1982) Purification and characterization of a unique isozyme of cytochrome from liver microsomes of ethanol-treated rabbits. J. Biol. Chem. 257, 8472-8480

Laemmli, U.K. (1970) Cleavage of structural proteins during the assembly of the head of bacteriophage T4. Nature 277, 680-685

Mauch, F., Staehelin, L.A. (1989) Functional implications of the subcellular localization of ethylene-induced chitinase and $\beta-1,3-$ glucanase in bean leaves. Plant Cell 1, 447-457

Mauch, F., Mauch-Mani, B., Boller, T. (1988) Antifungal hydrolases in pea tissue. II. Inhibition of fungal growth by combinations of chitinase and 8-1,3-glucanase. Plant Physiol. 88, 936-942

Mirelman, D., Galun, E., Sharon, N., Lotan, R. (1975) Inhibition of fungal growth by wheat germ agglutinin. Nature 256, $414-416$

Peumans, W.J., Stinissen, H.M., Carlier, A.R. (1982) Isolation and partial characterization of wheat-germ-agglutinin-like lectins from rye (Secale reale) and barley (Hordeum vulgare) embryos. Biochem J. 203, 239-243

Peumans, W.J., De Ley, M., Broekaert, W.F. (1983) An unusual lectin from stinging nettle (Urtica dioica) rhizomes. FEBS Lett. $177,99-103$

Price, J.S., Storck, R. (1975) Production, purification and characterization of an extracellular chitosanase from Streptomyces. J. Bacteriol. 124, 1574-1585

Rupley, J.A. (1964) The hydrolysis of chitin by concentrated hydrochloric acid, and the preparation of low-molecular-weight substrates for lysozyme. Biochim. Biophys. Acta 29, 522-534 
Schlumbaum, A., Mauch, F., Voegeli, V., Boller, T. (1986) Plant chitinases are potent inhibitors of fungal growth. Nature 324, $365-367$

Tata, S.J. (1975) Hevein: its isolation, purification and some structural aspects. In: Proc. Int. Rubber Conference, Kuala Lumpur, vol II, pp. 499-517, Rubber Res. Inst. Malaysia, Kuala Lumpur

Tata, S.J., Beintema, J.J., Balabaskaran, S. (1983) The lysozyme of Hevea brasiliensis latex: isolation, purification, enzyme kinetics and a partial amino acid sequence. J. Rubber Res. Inst. Malays. $31,35-42$

Walsh, K.A. (1970) Trypsinogens and trypsins of various species.
In: Methods of enzymology, vol XIV, pp. 41-63, Perlmann, G.E., Lorand, L., eds. Academic Press, New York, London

Walujono, K., Scholma, R.A., Beintema, J.J., Mariono, A., Hahn, A.M. (1975) Amino acid sequence of hevein. In: Proc. Int. Rubber Conference, Kuala Lumpur, vol II, pp. 518-531, Rubber Res. Inst. Malaysia, Kuala Lumpur

Wessels, J.G.H. (1988) A steady-state model for apical wall growth in fungi. Acta Bot. Neerl. 37, 3-16

Wright, H.T., Brooks, D.M., Wright, C.S. (1985) Evolution of the multidomain protein wheat germ agglutinin. J. Mol. Evol. 21, 133-138 